\title{
Judgment in law and the humanities
}

\section{Abstract:}

One of the central questions that the influence of the humanities on law raises is this: how, and with what legitimacy, can judgment take place if the texts on which judges base their decision do not - even in principle, let alone in practice - yield 'one right answer.' Over the past few years, as the question of judgment has ever more urgently weighed upon scholars within the broad church of the humanities, at least two kinds of answer have emerged: one broadly speaking influenced by Derrida's later work and the other, equally schematically, taking Heidegger as its point of departure. Now these two streams draw very closely on a common intellectual tradition and share many points of

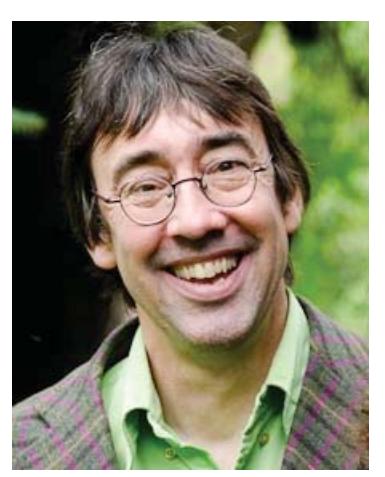
similarity. Both, for example, think that positivism is incapable of either adequately describing the nature of legal reasoning or seriously justifying its core claim that law is a system of determinates rules capable of neutral application. In this chapter I focus on these two divergent paths now open to law and the humanities. The key difference between them (although not everyone will agree) lies in the transcendentalism - I would say the Romanticism - of the latter, and the relativism I would say the humanism - of the former. The difference between the two strands of anti-positivism generated by recent work in law and the humanities has profound implications for our understanding of what it means to interpret a law or to make a legal decision. Secondly, we have both social and intellectual reasons to prefer the humanist perspective over its Romantic alternative. Drawing on the language of deconstruction, and the experience of literature that lies at its heart, I want to defend an understanding of the purpose and nature of legal judgment which places as its central concern the provisional and multi-vocal experience of human discourse. From this we might develop a theory of judgment that is neither positivist nor Romantic.

\section{Rezumat:}

Una dintre întrebările centrale care influențează științele umaniste privind dreptul este aceasta: cum și cu ce legitimitate, poate avea loc judecata dacă textele pe care

\footnotetext{
*E-mail professional contact: desmond.manderson@anu.edu.au.

Professor Desmond Manderson is an international leader in interdisciplinary scholarship in law and the humanities. He is the author of several books including From Mr Sin to Mr Big (1993); Songs Without Music: Aesthetic dimensions of law and justice (2000); Proximity, Levinas, and the Soul of Law (2006); and Kangaroo Courts and the Rule of Law-The legacy of modernism (2012). His work has led to essays, books, and lectures around the world in the fields of English literature, philosophy, ethics, history, cultural studies, music, human geography, and anthropology, as well as in law and legal theory. Throughout this work Manderson has articulated a vision in which law's connection to these humanist disciplines is critical to its functioning, its justice, and its social relevance. After ten years at McGill University in Montreal, where he held the Canada Research Chair in Law and Discourse, and was founding Director of the Institute for the Public Life of Arts and Ideas, he returned to Australia to take up a Future Fellowship in the colleges of law and the humanities at ANU.
} 
judecătorii își bazează deciziile nu se axează, măcar în principiu, să nu mai vorbim în practică, pe un singur răspuns corect. De-a lungul ultimilor ani, cum chestiunea judecății s-a ridicat mai urgent printre oamenii de știința din paleta științelor umaniste, cel puțin două tipuri de răspuns au apărut: unul' influențat pe larg de operele ultime ale lui Derrida și celălalt, la fel de schematic, luând pe Heidegger ca punct de plecare. Acum cele două curente țin foarte strâns de o tradiție culturală comună și împărtășesc multe puncte similare. Ambele, spre exemplu, apreciază că pozitivismul este incapabil atât de o descriere adecvată a naturii raționamentului legal cât și de o justificare serioasă a bazei sale pretinzând că legea este un sistem de a determina reguli capabile de aplicare neutră. În acest articol, autorul se concentrează pe cele două curente divergente deschise acum legii și științelor umaniste. Diferența esențială dintre ele se află în transcedentalism - ar spune autorul romantism - al ultimului, și în relativism al ultimului - umanism ar spune autorul. Diferența dintre cele două componente ale antipozitivismului generate de activitatea recentă în drept și științele umaniste are profunde implicații pentru înțelegerea noastră asupra a ceea ce înseamnă a interpreta o lege sau a emite o decizie. În al doilea rând, există motive sociale și intelectuale pentru a prefera perspectiva umanistă față de alternativă romantică. Bazându-se pe limbajul deconstrucției și experiența literaturii din interiorul acestuia, autorul dorește să apere o înțelegere a scopului și naturii hotărârii judecătorești care își plasează ca centru de interes experiența predicțională și multi-vocală a discursului umanist. Pornind de la aceasta se poate dezvolta o teorie a judecății care nu este nici pozitivistă nici romantică.

Keywords: judgment, decision making, legal positivism, anti-positivism, Romanticism, humanism, transcendence of justice

\section{Introduction}

To he interdisciplinary temperament of 'law and the humanities' is both perplexing for law, and intriguing for the humanities. This perplexity and this intrigue come to a head precisely over one of the most important institutional necessities and problems of law: judgment. If a text is not a truth but a debate; if it embodies not one story or meaning but many; if a statute, let us say, or a court case cannot be neatly separated from literature, or rhetoric, or politics - then there is literature, and rhetoric, and politics, in every interpretation and in every decision. A philosophical treatise can be subversive, open-ended, speculative; a literary reading probably should be. But a judge must decide: what this text means, whether this statute applies, who wins, who loses; even, sometimes, who lives and who dies. 45 One of the central questions that the influence of the humanities on law raises is this: how, and with what legitimacy, can judgment take place if the texts on which judges base their decision do not - even in principle, let alone in practice - yield 'one right answer.' The question of judgment becomes then a serious problem. It is a problem for positivists, of course, who entirely reject this approach to interpretation and meaning. But it is no less a problem for scholars of the humanities in law, who have to try and find an answer to it if they wish to be relevant to legal institutions at all.

Over the past few years, as the question of judgment has ever more urgently weighed upon scholars within the broad church of the humanities, at least

${ }^{45}$ Austin Sarat, When the State Kills (Princeton, NJ: Princeton University Press, 2002).

44 Revista Forumul Judecătorilor - Nr. 1/2013 
two kinds of answer have emerged: one broadly speaking influenced by Derrida's later work ${ }^{46}$ and the other, equally schematically, taking Heidegger as its point of departure. ${ }^{47}$ Now these two streams draw very closely on a common intellectual tradition and share many points of similarity. Both, for example, think that positivism is incapable of either adequately describing the nature of legal reasoning or seriously justifying its core claim that law is a system of determinates rules capable of neutral application. Nevertheless I wish to insist in this essay that the two strands part company on the crucial question of judgment in law.

I have chosen two paradigmatic texts to highlight this comparison: Derrida's "Force of Law," and a recent history of German legal positivism by Roger Berkowitz. ${ }^{48}$ The former, of course, is one of the field's seminal contributions. The latter is exemplary, I think, because it addresses the question of judgment and justice explicitly. In so doing it draws out
Heideggerian resonances which we find in a number of recent works: in much of Philippe Nonet's extraordinarily imagined work on Heidegger and on the Greeks, in the elegant and persuasive historical work of Marianne Constable's Just Silences, in the exceptionally careful scholarship of Mark Antaki's critiques of human rights, and in Richard Weisberg's recent research on Nietzsche, to name but a few. ${ }^{49}$ One might go further and note the more general burgeoning of interest within legal academia in not only Heidegger but Carl Schmitt. ${ }^{50}$

In this chapter I focus on these two divergent paths now open to law and the humanities. The key difference between them (although not everyone will agree) lies in the transcendentalism - I would say the Romanticism - of the latter, and the relativism- I would say the humanism of the former. Neither am I content to simply note this split. Could a scholar committed to law and the humanities sit on the fence, pretending to impartially
46 Jacques Derrida,"Force of Law: The Mystical Foundation of Authority," (1990) 11 Cardozo Law Review 919-1045, 959; Jacques Derrida, Acts of Religion, ed. Gil Anidjar (New York: Routledge, 2002), 228-98. See also, for example, The Gift of Death (Chicago: University of Chicago Press, 1995); On Cosmopolitanism and Forgiveness, trans. Mark Dooley and Michael Hughes (Routledge: London, 2002).

${ }^{47}$ See for example, lan Ward, Law, Philosophy and National Socialism: Heidegger, Schmitt, and Radbruch (Herbert \& Cie Lang AG, 1992); Oren Ben-Dor, Thinking about Law: In Silence with Heidegger (Oxford: Hart Publishing, 2007).

${ }^{48}$ Roger Berkowitz, The Gift of Science: Leibniz and the Modern Legal Tradition (Cambridge, Mass.: Harvard University Press, 2005).

${ }^{49}$ Philippe Nonet,"Antigone's Law" (2006) 2 Law Culture and the Humanities 314-35;"What is Positive Law?" (1990) 100 Yale Law Journal 667;"Technique and Law" in Kagan, Krygier and Winston, eds., Legality and Community (New York: Rowman, 2002); Marianne Constable, Just Silences: The Limits \& Possibilities of Modern Law (Princeton: Princeton University Press, 2005); Mark Antaki, "The World(lessness) of Human Rights" (2004) 49 McGill
Law Journal 203; Genealogy of Crimes Against Humanity, unpublished doctoral dissertation, University of California Berkeley, 2005; Richard Weisberg,"Nietzsche's Hermeneutics: Good and Bad Interpreters of Texts," in Peter Goodrich and Mariana Valverde, eds., Nietzsche and Legal Theory: Half-Written Laws (New York: Routledge, 2005).

${ }^{50}$ See for example in addition to the previous footnote, lan Ward, Law, Philosophy and National Socialism: Heidegger, Schmitt, and Radbruch (Herbert \& Cie Lang AG, 1992); Oren Ben-Dor, Thinking about Law: In Silence with Heidegger (Oxford: Hart Publishing, 2007); Gillian Rose, Dialectic of Nihilism, Post-structuralism, and Law (Oxford: Blackwell, 1984); David Dyzenhaus: Law as Politics: Carl Schmitt's Critique of Liberalism (Chapel Hill: Duke University Press, 1998); Mark Antaki, "Carl Schmitt's Nomos of the Earth" (2004) 42 Osgoode Hall Law Journal 317; Carl Schmitt, Political Theology: Four Chapters on the Concept of Sovereignty, ed. George Schwab (Chicago: University of Chicago Press, 2006); Legality and Legitimacy (Chapel Hill: Duke University Press, 2004); Giorgio Agamben, State of Exception, trans. Kevin Atell (Chicago: University of Chicago Press, 2005).

Revista Forumul Judecătorilor - Nr. 1/2013 
describe a discourse rather than actively engaging in its evolution? No, I am not a judge hiding my opinions like lingerie beneath the long black robes of law's neutrality. ${ }^{51}$ There is an argument in this chapter. First, there is a lot at stake here. The difference between the two strands of anti-positivism generated by recent work in law and the humanities has profound implications for our understanding of what it means to interpret a law or to make a legal decision. Secondly, we have both social and intellectual reasons to prefer the humanist perspective over its Romantic alternative. Drawing on the language of deconstruction, and the experience of literature that lies at its heart, I want to defend an understanding of the purpose and nature of legal judgment which places as its central concern the provisional and multi-vocal experience of human discourse. From this we might develop a theory of judgment that is neither positivist nor Romantic.

\section{Critiques of positivism and the transcendence of justice Force of Law}

For many years now, legal positivism has come in for a barrage of criticism: first from realists ${ }^{52}$ and Marxists, ${ }^{53}$ in the wake of the civil rights movement from feminists and race theorists, in the 1980s from critical legal studies. ${ }^{54}$ The highlight of the past fifteen years has been the contribution of deconstruction ${ }^{55}$ to this critique. For Derrida, justice embodies two opposing impulses: equal treatment and singular respect. It expresses an aspiration towards"law or right, legitimacy or legality, stabilisable and statutory, calculable, a system of regulated and coded prescriptions ${ }^{\prime \prime 6}$ and at the same time the desire for a unique and singular response to a particular situation and person asking for our help. Justice is general and unique; it involves treating everybody the same and treating everybody differently, applying the law... and not.

Our common axiom is that to be just or unjust and to exercise justice, I must be free and responsible for my actions, my behaviour, my thought, my decision. But if the act simply consists of applying a rule, of enacting a program or effecting a calculation, we might say that it is legal, that it conforms to law, but we would be wrong to say that the decision was just... In short, for a decision to be just and
51 See"Black robes with humans inside them," New York Times, 12 December 2000, p. A1.

${ }^{52}$ Karl Llewellyn, Jurisprudence: Realism in Theory and Practice (Chicago, University of Chicago Press, 1962); Jerome Frank, Law and the Modern Mind (New York: Brentano's, 1930); Julius Stone, Legal System and Lawyer's Reasonings (Stanford, Calif.: Stanford University Press, 1964).

${ }^{53}$ See the discussion in Cameron Stewart,"The Rule of Law and the Tinkerbell Effect: Theoretical Considerations, Criticisms and Justifications for the Rule of Law" (2004) 4 Macquarie Law Journal 135164; Evgeny Pashukanis, Selected Writings on Marxism and Law, eds. P. Beirne \& R. Sharlet (London \& New York: Academic Press, 1980).

${ }^{54}$ The citations would be endless: see Jorge Borges, "The Library of Babel" in Ficciones (New York: Grove Press, 1962 [1956]) 79-89. Purely for notable illustrations, I refer the reader to the work of Roberto Unger, Knowledge and Politics (New
York: Free Press, 1984); The Critical Legal Studies Movement (Cambridge, Mass.: Harvard University Press, 1986); Mark Kelman,"Trashing," (1984) 36 Stanford Law Review 293; and for feminist critiques of positivism, see the work of Catherine MacKinnon, Towards a Feminist Theory of the State (Cambridge, Mass.: Harvard University Press, 1991).

${ }^{55}$ Derrida,"Force of Law"; Dennis Patterson, ed. Postmodernism and Law (Dartmouth: Ashgate, 1994); Allan Hunt,"The Big Fear: Law Confronts Postmodernism," 35 McGill Law Journal 507; Jack Balkin, Deconstructive Practice and Legal Theory, 96 Yale L. J. 743 (1987); Costas Douzinas, Peter Goodrich, and Yifat Hachamovitch, Politics, Postmodernity and Critical Legal Studies: The Legality of the Contingent (London: Routledge, 1994); Costas Douzinas, Ronnie Warrington and Shaun McVeigh, Postmodern Jurisprudence: The law of texts in the texts of law (London: Routledge, 1991).

${ }^{56}$ Derrida,"Force of Law".

46 Revista Forumul Judecătorilor - Nr. 1/2013 
responsible it must, in its proper moment if there is one, be both regulated and without regulation: it must conserve the law and also destroy it or suspend it enough to have to reinvent it in each case. 57

If we could separate justice from law then this would not pose a problem. Lawyers could just apply the rules, and think about justice on their day's off. This is of course the strategy adopted by most standard positivist theories of judgment. ${ }^{58}$ But every legal decision requires us to make a judgment as to the applicability of prior general norms to the necessarily different and singular situation before us. Although cases in what HLA Hart called the 'penumbra' dramatize it, in fact every case requires us to make the same kind of choice. We must still judge if this unique case is 'the same as' or 'different from' the past, and this is of course the very judgment that the past cannot ever help us with. It does not matter whether we are talking about legal judgment in the context of statutory interpretation, a Code, a Constitution, or case law. The necessary passage of time between the enunciation of a norm and its application, and the necessary uniqueness of the present judgment by comparison to its prior instances, inevitably opens up a space for decision. 59

The paradoxical choice and conflict that judgment always opens up, then, is hard-wired into law no less than justice. Both demand of us that we respect the rules in their utmost generality and the individual in his utter specificity; that we attend to the constructive power of the past as a way of controlling the future, and the re-constructive power of the present as a way of reinterpreting that past. This complicated backwardsand-forwards dynamic is essential to all decision-making - to all reading, say the humanities - and no rules could ever tell us exactly how to accomplish it. Samuel Beckett wrote,"we are not merely more weary because of yesterday, we are other." 60 Perhaps we are only a little bit more weary than yesterday, or a little bit other; but we can never know that without first thinking about it. The judge is bound, says the positivist. The judge is bound to choose, say I.

Accordingly, an element of incalculability, irreducible to formal rules necessarily enters into the moment of legal judgment. This element continually unsettles our established rule and categories and forces us to re-open their meaning at the very moment we apply them. Neither justice nor law are capable of being reduced to"juridical-moral rules, norms or representations, with an inevitable totalising horizon", some one-way track by which the past could stop us thinking in the present about the future. In law as in language ${ }^{61}$ in philosophy as in literature, such a tyranny is simply not possible. The meaning of a text always has the possibility of changing in light of changed circumstances. This is not a
57 Id., 961.

${ }^{58}$ H L A Hart,"Positivism and the Separation of Law and Morals," (1957-8) 71 Harvard Law Review 593; Joseph Raz, The Authority of Law (Oxford: Clarendon Press, 1979); Tom Campbell, The Legal Theory of Ethical Positivism (Dartmouth: Ashgate, 1996); Andrei Marmor,"Legal Positivism: Stil Descriptive and Morally Neutral" (2006) 26 Oxford Journal of Legal Studies 683-704. In some ways, these views all go back to the great work of Hans Kelsen, General Theory of Law and State, trans.
Wedberg (1945).

59 Richard Beardsworth, Derrida and the Political (London and New York: Routledge. 1996) 110. Gerald Postema, 1991)"On the Moral Presence of our Past", (1991) 36 McGill Law Journal 11531180.

60 Samuel Beckett, Proust (London: Grove Press, 1957 [1931]), 3.

61 Jacques Derrida, Of Grammatology, trans. Gayatri C. Spivak (Baltimore: Johns Hopkins Univ. Press, 1976 [1967])

Revista Forumul Judecătorilor - Nr. 1/2013 
tragedy. On the contrary, as Derrida remarks, "we may even see in this a stroke of luck for politics, for all historical progress."62

This is hardly so very different from what was said, long before, by Lon Fuller. In debating Hart, he too insisted that it is just not possible to apply a rule without being forced, in some measure, to consider its meaning in relation to a greater framework or set of principles that are themselves, if they are not to fall foul of the logic of infinite regression, incapable of reduction to a perspicuous form of words. ${ }^{63}$ So positivist theories find themselves confronted by a challenge based on the nature of 'law' and the nature of 'language'; a challenge that points to the illimitable moment of judgment that lies at the core of legal interpretation.

The problem, not just for lawyers I think but for anyone interested in social justice, is that such an approach to interpretation equally challenges the standard theory of the rule of law. It too sets great store by the idea that judges, in 'following' the law, are simply applying guidelines whose implications are already well-known (or at least knowable) by the community. ${ }^{64}$ As Hart wrote, "if it were not possible to communicate general standards of conduct which multitudes of individuals could understand, without further direction, as requiring from them certain conduct when occasion arose, nothing that we now recognize as law could exist." 65 Accordingly, as Langille observes, if"language is indeterminate, unstable, subject to manipulation and incapable of expressing rules and principles which constrain judges...the law is a failure on its own terms and the virtues of the rule of law are impossible to secure." 66 If the rule of law involves certainty of judgment, ${ }^{67}$ the implications of connecting law to the humanities, and jurisprudence to continental philosophy, are problematic to say the least.

This essay is not interested in looking at positivist responses to this critique. ${ }^{68}$ Yet although I find myself persuaded by Derrida's approach to the problem of judgment, there is nevertheless plenty here that still troubles me. Practically, what can the rule of law mean in light of this critique? Philosophically, what are the implications of this account of justice? If justice involves "madness", "a moment of undecidability" 69 in which the judge merely intuits what true justice demands referable to nothing but his own manifest sense of it, like some invisible trump, what then? Have we simply replaced the positivists' tyranny of the text with a priesthood of judges? Are we replaying the Reformation, which once before pitted direct communication with God against the primacy of the written word - only this time in reverse?
62 Derrida,"Force of Law," 949.

${ }^{63}$ Lon Fuller,"Positivism and Fidelity to Law: A Reply to Professor Hart," (1957-8) 71 Harvard Law Review 630.

64 H.L.A. Hart, Concept of Law (Oxford: Clarendon Press, 1960), and 'Positivism'; Heydon Dyson, "Judicial Activism and the Rule of Law" (2003) 23 Australian Bar Review 110; John Gava,"Another Blast From The Past Or Why The Left Should Embrace Strict Legalism" (2003) 27 Melbourne University Law Review 7.

65 Hart, Concept, 121. Italics added.

66 Brian Langille,"Revolution without Foundation: The Grammar of Scepticism and Law," (1988) 33 McGill Law Journal 451, 455.
${ }^{67}$ Lon Fuller, The Morality of Law (New Haven: Yale University Press, 1964); Colleen Murphy, “The Moral Value of the Rule of Law" (2005) 24 Law and Philosophy 239-262; Tom Campbell, Legal Theory, and Justice, $2^{\text {nd }}$ ed. (London \& New York: Macmillan, 2001).

${ }^{68}$ But see for a careful reflection on many of these issues, Peter Drahos and Stephen Parker,"The Indeterminacy paradox in law"“ (1991) 21 University of Western Australia Law Review 305319; and"Rule Following, Rule Scepticism and Indeterminacy in Law: A Conventional Account" (1992) 5 Ratio Juris 109-119.

69 Derrida,"Force of Law." 


\section{The Gift of Science}

My concern has been further sharpened by a new historical critique of legal positivism that touches on these very points. The Gift of Science, by Roger Berkowitz, offers legal history refracted through Heidegger, ${ }^{70}$ and stands I think for one way in which the challenge which law and the humanities poses to the question of legal and institutional judgment might be met. Berkowitz draws on approaches to the relationship of law and justice which, as I noted earlier, have been developing amongst a number of writers in recent years. Nevertheless I choose in this essay to focus on Berkowitz because he directly confronts the question of legal judgment - how is it to be understood and how is it to be justified? And because in so doing he defends explicitly - perhaps, in fairness to other commentators such as Constable, the word 'starkly' would be better - the social and institutional implications of his answers.

The Gift of Science studies with great care the German positivist tradition from the late seventeenth century up to the enactment of that pinnacle of legal systematization, the Bürgerliches Gesetzbuches (BGB) of 1900. We might summarize Berkowitz' thesis as follows: 'modernity' in law involves the attempt to do without God as the foundation and origin of law. We see this first in Leibniz, though he remains a transitional figure in many ways (as was Newton in other fields), and then with increasing force in the theorists of German positive law who followed: Svarez, Savigny, Jhering. Absent God, 'law' ceases to be a coherent entity with an"existence outside of its posited existence in rules, norms, and conventions" ${ }^{\prime \prime 1}$. This creates a problem for law's authority. Without God - or nature, or tradition, for that matter - who is to say what justice really requires of us?

The answer given in modernity goes by the name of science or, we might say, the objective text. ${ }^{72}$ 'Science' is used compendiously here to suggest a way of thinking that has in many fields aimed to provide empirical, verifiable, objective answers to problems, grounded in certainties of logic, reason, and human knowledge. Science is the opposite of faith: it is proof not truth, human not divine. This was the 'gift' that was intended to give back to law the sure foundation that had been destroyed.

Leibniz's introduction of the principle of sufficient reason into jurisprudence promised to give law the scientific grounds for its authority that it so dearly desires... Similarly, law too must have a reason posited for it if it is to exist. Law, in other words, does not exist in and of itself as a natural or traditional insight into what is right and fitting... Law is subordinated to its reasons and justifications. ${ }^{73}$

In the place of authority, mere justifications; in the place of justice, mere law; in the place of Recht or droit, a coherent body of eternal principles, gesetz or lois, a vast and constantly expanding list of interdictions and procedures produced in conformity with and changeable by human will. This is the story of 'modern law' from Leibniz to the $B G B$.

Using the inter-disciplinary tools of law and the humanities, one could easily expand our perspective and see similar trends throughout the West, as ideas of religious or inherent authority weakened. In classical music, to take one example, we see at the time of the Enlightenment the decline of improvisation and its

70 Berkowitz, The Gift of Science, eg. $\quad 72$ Id., 156. Introduction.

${ }^{71}$ Id., xvi. 
replacement by increasingly detailed instructions which aim to bind performers to the composer's will. This too reorients authority from the present to the past and from the spirit to the letter of the law; it marks a shift in the locus of meaning from the insightful creativity of the judge/ performer to the procedurally-legitimated straitjacket imposed by the legislator/ composer. ${ }^{74}$ Indeed, the Reformation itself was part of this great historical transition from faith to science, from authority to reason, and from judges' responsibility to unique persons to their obedience to general texts. ${ }^{75}$

Berkowitz' arguments go well beyond historical analysis. They concern the present not the past. These arguments are not presented in a systemic form, but they appear insistently throughout the book and reflect a deeply held set of commitments. Berkowitz does us a great service in putting his cards on the table. "The gift of science," he argues, is a poisoned chalice that did and must fail to provide law with the certainty, the decision-making capacity, and the justification that it seeks. One can see in this argument an affinity with the deconstruction of rules, and the relationship between law and justice, which we observed above. On the one hand,"to say that 'deconstruction is justice' ... is to insist, rightly, that law cannot be separated from an ideal of transcendental justice..." On the other, it is only once modern law becomes a"product of scientific knowledge ... willed, posited, and in need of scientific justification", from which the transcendent element of law has been rigorously excluded, that"the indeterminacy of law comes to be such a forbidding problem."76

Berkowitz draws from this several important conclusions that concern not only change but loss. In the first place, with the rise of positivism we have lost the relationship between law and justice which for Berkowitz is crucial to the act of judgment. Indeed, the plea to re-forge that relationship runs through The Gift of Science from the very first sentence: "Justice has fled our world."77 This justice is posed throughout as "transcendent" ${ }^{78}$ The scientific objectivity that modern law promises but fails to deliver suppresses precisely"the legal idea of justice... in its connection with transcendence... the beautiful dream of transcendence."79 $T$ The meaning of justice as transcendence is never adequately explained. We could see it in the context of Derrida or even, perhaps, Fuller. Berkowitz, following Nonet, following Heidegger, goes much further than this. Justice for him imports insight into the "ethical unity" of law. ${ }^{80}$

Justice as law's"ethical unity" appears to transcend not only specific rules but also individual or conflicting interests in favour of the unification of the community."Active thinking .... is irreducible to rules or laws... Similarly, justice demands that man think and in thinking transcend the limits of his unique self and enter into an ethical community with others. The dream of justice, in other words, is the dream of transcendence." 81

The second loss is"that law might actually be - that it might actually have an existence - outside of its posited

\footnotetext{
${ }^{74}$ See Desmond Manderson,"Et Lex Perpetua: Formalism in Law and Music" (1999) 20 Cardozo L. Rev. 1621-48;"Statuta v Acts" 7 Yale Journal of Law \& Humanities (1995) 317-366.

75 David Trubek,"Max Weber on law and the rise of capitalism" (1972) Wisconsin Law Review 720-53; Max Weber, Law in Economy and Society(Cambridge, Mass.: Harvard University
}

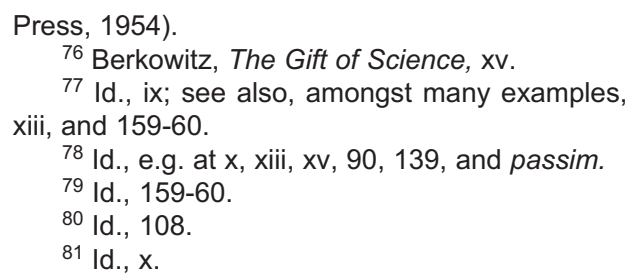

50 Revista Forumul Judecătorilor - Nr. 1/2013 
existence in rules, norms, and conventions..."82 Here we begin to see the powerful anti-humanism of Heidegger, which clearly forms the philosophical spine of these suppositions, as read through Philippe Nonet's influential work on Heidegger and law, to which Berkowitz amongst others is deeply indebted. ${ }^{83}$ Law is "more than human". It is not just our tool to fashion and justify as we wish. On the contrary, it"exists in and of itself," preceding human needs or social ambitions. It is the emanation of an "already presupposed ethical world." 84

What we have seen so far is that legal judgment, on this view, cannot be tied down to the failed positivist faith in pre-existing rules and objectively interpreted texts. What is proposed to replace it is the judge who has a sense of justice that transcends not just the rules, but the human and social world itself. How is this unified ethical world to be discerned? The third loss for Berkowitz, and it is one to which he returns repeatedly, is the "loss of insight"."Natural law... previously knowable only through a free and active insight into an incalculable yet manifest sense of divine and human justice, increasingly assumes the character of an instrument of scientifically knowable will." Elsewhere this insight is referred to as "natural" while the "scientific knowing of law" is characterized - in language which might recall for us that of Sir Edward Coke as"artificial". ${ }^{85}$ So on this view, true judgment occurs through an"insightful activity of justice" 86 which, as the word implies, is not to be articulated and still less to be justified. It is to be divined.
Divined is the right word. For if one wonders who is to be entrusted with this insightful activity, one encounters a fourth loss - that of authority. For Berkowitz, authority, too, is natural and intrinsic. It is the opposite of 'legitimacy' that, like rules or the norms of social justice, demands that the judge be held accountable for his decisions by the giving of reasons. Indeed, we need this constant questioning and justification of decisions precisely because"law loses its natural claim to authority."87 Authority, like justice and insight, does not require justification. ${ }^{88}$ Instead, it is founded in what is variously called 'nature' or 'tradition' or 'religion'. It is "the natural connection with the divine" 89 - note, natural - and law's"necessary connection to the ineffable" 90 - note, necessary - that grants this authority, provides this insight, comprehends this unity, and imparts this transcendence. The greatest loss in a litany of losses is the loss of God.

Berkowitz does not merely describe a vanished world view: he advocates for its renaissance. The word 'insight' shows us how closely Berkowitz, along with others working in this tradition, allies himself to an approach to law that has been corrupted by positivist science. The scholar who comes in for the most sympathetic attention is Savigny. And in Berkowitz' analysis, the key word that underscores his approval of Savigny is 'insight'. Savigny fights a rearguard action in attempting to return the practice of insight to law. ${ }^{91}$ Throughout, there is a fusion between Savigny's ideas about insight, Savigny as himself blessed with

\footnotetext{
82 Id., xvi.

83 Id., e.g. x, xx, 11, 28. See in particular Nonet, "Antigone's Law" and“Technique and Law." 84 Id., 139, 51, xii.

85 Berkowitz, 24, 107. See Edward Coke, Prohibitions del Roy (1608) 12 Co. Rep. 63; 77 E.R. 1342.
} 
insight, and his approach which merits the accolade"insightful." 92 Nothing could be clearer then, but that the very same insight that marks the pre-scientific approach to law, is the foundation of Berkowitz' own. An intense longing pervades the book, as it is equally clear in Nonet that there"would seem to be a mourning, or, rather, melancholic longing for a lost utopia, a world without the things the law decides."93

\section{From loss to lack}

\section{The deconstructive moment}

My question is: is this the shore on which the search for judgment has been beached? Have we escaped the Scylla of formalism only to be cast into this Charybdis of unreason? More specifically, does this version of judgment as transcendence necessarily follow from the critique of positivism I outlined above ${ }^{94}$ Suppose one accepts that a responsible legal judgment must"be both regulated and without regulation: it must conserve the law and also destroy it or suspend it enough to have to reinvent it in each case." "55 Suppose that some idea of justice is a necessary element of legal interpretation but is indeed irreducible to a Code or gesetzbuch. Must one fall back on those figures whose loss Berkowitz mourns: authority unquestioned, justice ineffable, law natural, God? And if not, where precisely is the exit ramp?

Many have read Derrida this way. Jack Balkin, for one, insists that justice for Derrida is indeed "transcendent:" unreasoned, inexplicable, and instinctive. ${ }^{96}$ So too Gillian Rose takes to task the "new ethics" of "Messianic deconstruction" - in which she includes both Levinas and Derrida because it disdains justification in favour of a"sacralized polity." 97 In a remark that seems apposite, she proclaims herself committed"to return philosophy from her pathos to her logos."98

However fair this criticism might be of Levinas $^{99}$ or, though with quite other implications, of Heidegger, I think a very different reading of Derrida is possible and it is that reading that I attempt here, drawing in particular on"Force of Law," not to mention his forceful rejection of Searle's criticism of him in the "Afterword" to Limited Inc. ${ }^{100}$ It has sometimes between said that my own reading of deconstruction and law is too generous, and even perhaps too creative a view of its ambiguous mystifications. Perhaps, and if what follows is my effort to develop
92 Id., 121-29.

93 Andrew Norris,"Heideggerian Law Beyond Law?" (2006) 2 Law, Culture and the Humanities 341,348 .

94 Balkin, for one, lumps together all these approaches as species of "anti-humanist philosophy", though the term in relation to Derrida is too bizarre to require further attention here: Jack Balkin,"Deconstruction's Legal Career" (2005) 27 Cardozo Law Review 719, 719-20, and passim.

95 Derrida,"Force of Law," 961.

96 Jack Balkin,"Deconstruction's Legal Career"; "Transcendental Deconstruction, Transcendent Justice," (1994) 92 Mich. L. Rev. 1131; Christopher Norris, Deconstruction: Theory and Practice (London: Routledge, 1991).

${ }^{97}$ Gillian Rose, Judaism and Modernity (Oxford: Blackwells, 1993) 87; The Broken Middle (London: Blackwells, 1992) 293. Rose's target here is the work of Emmanuel Levinas but she is also happy to encompasses Derrida in a searing critique. For a further discussion of Rose's critique in relation to Levinas and to Derrida, see Desmond Manderson, Proximity, Levinas, and the soul of law (Montreal: McGill-Queen's University Press, 2006) 73-81, 195.

${ }^{98}$ Rose, Broken Middle, 310.

99 Desmond Manderson, ed., Essays on Levinas and Law (London \& NY: Macmillan, 2008)

100 Manderson, Proximity, chapter 7; Derrida,"Force of Law"; Jacques Derrida,"Afterword" to Limited Inc. (Evanston, III.: Northwestern University Press, 1988). As Pierre Schlag has pointed out to me, it is nevertheless fair to say that Derrida's flirtation with the mysticism of "the madness of decision", no less than his ethereal and abstract discussion of justice, no doubt invite Balkin's interpretation.

52 Revista Forumul Judecătorilor - Nr. 1/2013 
a position on the question of legal judgment that builds on Derrida rather than simply explaining it, so be it.

The difference between justice-astranscendence and deconstruction-asjustice can be summed up in a single word. We have not lost the foundations of law. We lack them. This fantasy of God and unquestionable authority and of law as an eternal truth never existed, though the established order could always be relied upon to claim otherwise. Derrida insists throughout the entire body of his work, in relation to law and otherwise, on the iterability of language which renders necessarily unstable our concepts and ideas; on différance which renders infinitely questionable our structures of authority; on the constant collisions and paradoxes not just between our beliefs here in this community and their beliefs over there in that community, but within our words and beliefs and faiths and foundations themselves. Contrary to the utopian imagery of Nonet, our tradition is not whole; it was fractured ab initio. No one did this to it; it did this to itself. As Barbara Johnson writes in a passage which I take to be the very manifesto of law and the humanities:

The de-construction of a text does not proceed by random doubt or arbitrary subversion, but by the careful teasing out of warring forces of signification within the text itself... It is thus not out of hostility to the moral values of Western civilization that deconstruction has arisen, but out of a desire to understand how these values are potentially already different from themselves. By re-reading the texts of writers and philosophers that have made a difference to Western history, it might be possible to become aware of the repressions, the elisions, the contradictions and the linguistic slippages that have functioned unnoticed and that undercut the certainties those texts have been read as upholding. ${ }^{101}$

Deconstruction is relentless in drawing our attention to the conflicts and ambiguities we experience at every moment of our lives. ${ }^{102}$ It is dogged in insisting not on the 'ethical unity' of principles or texts, but on the contrary in urging us to recognize and to be constantly aware of the politics, the context, and the social implications of any and every such fallacious claim. For me, such an approach pits 'ethical' against 'unity'. It stands for the sheer impossibility of foundations, and for the toxic character of any rhetoric that purports to have escaped or preceded or risen above it.

Though we strive to make a judgment on the basis of the case before us and the texts that surround us, in the midst of the contradiction and aporia that deconstruction will not let us forget for an instant, and though the moment of decision that we all face requires us to make that leap without some certain rule to fall back upon, we do not thereby transcend the problem of judgment. We savour it; we endure it; we suffer it. ${ }^{103}$ This does not provide us with some stable ground, lost or otherwise; it makes us all too aware of the necessary lack of that ground.

In this way, the notion of justicebeyond-the-rules is not a new foundation or a perfected authority, but quite the opposite: new justifications and not an
101 Barbara Johnson,"The Surprise of Otherness: A Note on the Wartime Writings of Paul de Man," in Peter Collier and Helga Geyer-Ryan, Literary Theory Today (Ithaca: Cornell U P, 1990) 13-21, 18, 21.

102 See Beardsworth; Johnson; Aletta
Norval,"Hegemony after deconstruction” (2004) 9 Journal of Political Ideologies 139-157; Simon Critchley, The Ethics of Deconstruction, $2^{\text {nd }}$ ed (Edinburgh: Edinburgh University Press, 2000 [1991]).

103 Derrida,"Force of Law."

Revista Forumul Judecătorilor - Nr. 1/2013 
end to them, new doubts and not an end to them, new instabilities and not an end to them. Deconstruction suggests to me the need for a constant and unbending vigilance in the face of any claims of transcendence or authority or foundation - precisely in order to protect justice against its many well-wishers, paramours, and would-be proprietors. At the moment of judgment, these unresolved tensions and uncertainties become part of a never-ending discourse in which we all participate - indeed, in which our participation is unavoidable - and in which the change and argument and doubt surrounding a judgment become not symptoms of its failure but, in a deeper sense, of its success.

\section{The transcendental moment}

Where one response to the indeterminacy of rules speaks the loss of transcendence, I note a lack. Where Berkowitz grieves that"the whole simply lives no more"104 I can only remark that whatever roles the idea of this whole might have served in other societies, it has now a fantastic and too often a pernicious quality. Berkowitz presents us with a simple opposition: either we believe in the "beautiful dream" of "transcendent justice" based on "the ethical unity of law", or we must be satisfied with"modern conceptions of social justice based upon rules." 105 The point of this essay is to argue that these are not our only choices. The tradition of law and the humanities offers a third way. While the Heideggerian move seeks justice outside of discourse and language, the Derridean move maintains that no such outside exists. II n'y a pas de hors-texte. ${ }^{106}$ Whatever legal judgment can achieve - and we agree that objectivity and certainty is not an option - it achieves only through discourse.

When we try to discern what and who will find and realize for us transcendent justice, it is worth noting that Berkowitz typically qualifies the word authority and the word law with"natural". To rediscover the true meaning of law and justice, we must return to nature. Authority is a"natural claim" or a"natural and traditional" one; it acts upon law's"natural connection to truth and justice" as a"natural and traditional" insight. ${ }^{107}$ Here is a word with a great and exceptionally problematic pedigree. I doubt that I am alone in being astonished at the amount of justificatory work it performs here. To speak of nature is already to speak of something outside discourse, selfevident, authoritative, and beyond reproach. ${ }^{108}$ Meanwhile its semantic vagueness allows it to stand for a variety of different ideological positions at once, and to slip seamlessly from one to the other. ${ }^{109}$ If authority and insight are both natural, well what could be more natural than that? But just who is to be the judge of what counts as natural? Who defines nature, and according to what terms? Whose interests are favoured by nature? Who gets to claim its marvelous protective mantle and so shield their actions from question? And whose judgments, on the other hand, are reduced to the realm of the unnatural, a word which has not lost
104 Berkowitz, The Gift of Science, 158 quoting Max Weber.

105 Id., x, 108

106 Jacques Derrida, Of Grammatalogy (Baltimore: John Hopkins University Press, 1977) 158.

107 Berkowitz, The Gift of Science, 3, 7, 51-2, 108.
108 See the deconstruction of nature/culture in relation to Rousseau in Derrida, Of Grammatology.

109 Anne Fernihough, Aesthetics and Ideology (Clarendon Press: Oxford, 1993) 32-4, discusses at some length Pierre Bourdieu's analysis of the multiple ideologies embedded in the word 'natural'. Indeed, see Philippe Nonet on this: "Antigone's Law", 323-4.

54 Revista Forumul Judecătorilor - Nr. 1/2013 
its power to silence?'110 'Nature' is the answer to no question; but it puts an end to questions. It is no wonder that a word like 'discrimination,' for example, now carries with it a whole lot of baggage that it did not have back in the good old days when it meant merely the recognition of 'natural' distinctions between people. Over time, we have learnt something about how that word has been wielded by actual persons living in actual societies.

The Gift of Science presents us with strongly etched dichotomies, one side of which is subject to a very careful historical and social critique, and the other side of which is not analyzed at all but offered up as a fantastic vision. This vision is not only devoid of all history or social context, but fuses together disparate ideas into an imagined "ethical unity." The steady references to authority, justice, or insight as"natural and traditional,"'traditional and religious", and so on, mix together as sources of justification social practice, history, politics, and ethics. ${ }^{111}$ In the process, the deep and immemorial conflict between the claims of nature and tradition and religion disappear, and to believe in one is necessarily to become committed to all. This is what Walter Benjamin meant by"the aestheticization of politics." ${ }^{112}$ On one side history, and against it myth. ${ }^{113}$ No wonder myth has the inside running. It solves problems aesthetically that remain unsolved in the real world.
Berkowitz' history stops at the high point of German positivism. But it's the history of what came next that interests me. A century ago, German writers overwhelmingly responded exactly as Berkowitz does to the intellectual poverty of positivism. Sometimes termed New Romanticism, the outpouring of writing around the turn of the century, by which Heidegger was profoundly influenced, ${ }^{114}$ rejected in almost identical terms the German obsession with mechanics, systems, technology, and positivism. There too we can observe the same fusion of nature, tradition, custom, religion; the same belief in justice as hierarchical and judgment as manifest. ${ }^{115}$ The political effects of this revolt against modernity were of course both radical and reactionary:

But was it not a contradiction to believe simultaneously in a revolutionary yet conservative change? By no means, as long as there was a metaphysical foundation, as long as one's doctrine of revolution did not call for new and radical social and economic reforms. Man did not advance progressively, discarding his traditions as they became useless; rather he was bound by eternal laws that had been established in the past and embodied in tradition... [The new Germany] had to revive and make operative in a new age the traditions of medieval messianism. ${ }^{116}$

Berkowitz elegantly retells the history of German positivism and in the process
110 While it is true that Nonet, for example in ibid., insists that our reading of the word nature in relation to the Greeks has, since Hegel, mistaken the meaning and implications of that term, Berkowitz, in a fashion that is crucial to the political and legal argument of the book, nevertheless fuses these different senses and connotations.

111 Berkowitz, The Gift of Science, e.g. 3, 10 15, 51, 52 .

112 Walter Benjamin, politics and aesthetics.

113 According to Roland Barthes, amongst others, myth is precisely the synthesis of conflicting claims through linguistic or semiotics structures: see the seminal essay"Myth Today" in Mythologies, trans. Annette Lavers (New York: Hill \& Wang, 1984 [1957]).

114 Pierre Bourdieu, The Political Ontology of Martin Heidegger (Stanford, Calif.: Stanford University Press, 1991).

115 George Mosse, The Crisis of German Ideology: Intellectual Origins of the Third Reich (New York: Grosset and Dunlap, 1964), e.g. 98, 4-6, 54, 33, 92.

116 Id., 281.

Revista Forumul Judecătorilor - Nr. 1/2013 
vigorously re-enacts the secret history of German New Romanticism. As $\mathrm{MH}$ Abrams puts it, the Romantic movement was primarily"a metaphysics of integration, of which the key principle is that of the 'reconciliation' or synthesis, of whatever is divided, opposed, and conflicting."117 Thus the three positions become clear. When it comes to legal judgment, positivism rejects the possibility of conflicting or divided interpretations, and deconstruction attempts to embrace the possibility, while the New Romantics attempt to reconcile or transcend it.

\section{A third way?}

\section{The novel}

Certain aspects of the tradition and development of the European novel offerus a good illustration of what 'a third way' might begin to look like. First, this literature's commitment to psychology pricks the hubris of philosophical abstractions. In the voice of women in particular - and the history of English literature in particular, over the past two hundred years, has been the emergence of the voices and the realities of women's lives ${ }^{118}$ - we hear a constant reminder of the cruelties and repression sustained by appeals to an authority so vague and entrenched as to remain as imperceptible, irresistible, and omnipresent as the mist.

Hegel famously remarked that women are"the everlasting irony in the life of the community." 119 He was thinking of Antigone and he was right, although he managed to draw from his observation entirely the wrong conclusion. ${ }^{120}$ Perhaps the systematic exclusion of women from political and philosophical discourse has led them - though of course hardly them alone or all of them - to exhibit a skepticism of grand theories and of the romance of violence and power. Irony, which is one of the gifts of literature, holds our great words and promises up, and examines them from a distance;"the distance we are obliged to assume towards our most 'authentic' dreams, towards the myths that guarantee the very consistency of our symbolic universe."121

Secondly, the novel offers us an alternative vision of the nature of judgment because I don't think it's excessive for me to claim that one of crucial features of its growth has been is its polyphonic character. It multiplies voices; it sets characters' perspectives against each other; it does not shy away from but embraces the resulting uncertainty. This embrace of uncertainty, particularly in the form of humour, sets it apart from either positivism or Romanticism. Milan Kundera argues that humour is perhaps the most important achievement of the European novel, from Don Quixote to the present day.

Humour: the divine flash that reveals the world in its moral ambiguity and man in his profound incompetence to judge others; humour: the intoxicating relativity of human beings; the strange pleasure that comes of the certainty there is no certainty. ${ }^{122}$
117 M H Abrams, The Mirror and the Lamp: Romantic Theory and the Critical Tradition (Oxford: Oxford University Press, 1971).

118 Again it would be ludicrous to provide a reading list, but for notable signposts of this history see Charlotte Bronte, Jane Eyre (1847); George Eliot, The Mill on the Floss (1860); Virginia Woolf, To the Lighthouse (1927), though the point is not about women writers but about the representation of the inner lives of women.

${ }^{119}$ G W F Hegel, The Phenomenology of Spirit, trans. A.V. Miller (Oxford: Oxford University Press, 1977) 288
120 For feminist critiques, see Kimberley Hutchings, Hegel and Feminist Philosophy (Edinburgh Polity Press, 2002); Susan Easton,"Hegel and Feminism," (1984) 38 Radical Philosophy; Alison Stone and S. Sandford, eds., Hegel and Feminism (1999) 22 Women's Philosophy Review.

121 Slavoj Zizek, 'Superego by Default', in Metastases of Enjoyment (London: Verso, 2004) 54-85, 82.

${ }_{122}$ Milan Kundera, “The Day Panurge no longer makes people laugh" 1-33, in Testaments Betrayed, trans. Linda Asher (London: Faber \& Faber, 1995), 32-3.

56 Revista Forumul Judecătorilor - Nr. 1/2013 
DH Lawrence took the argument still further, insisting that "the great discovery" of the novel lay in its fundamental hostility to any ideology of unity or of "a presupposed ethical world."

The novel is the highest form of human expression so far attained. Why? Because it is so incapable of the absolute. In a novel, everything is relative to everything else, if that novel is art at all. Every Commandment that ever issued out of the mouth of God or man, is strictly relative: adhering to the particular time, place and circumstance. And this is the beauty of the novel; everything is true in its own relationship, and no further. ${ }^{123}$

Such narratives, rich, internal, dynamic, and multiple, do not to resolve or synthesize tensions but on the contrary to bring them out.

The artist usually sets out - or used to - to point a moral and adorn a tale. The tale, however, points the other way, as a rule... Never trust the artist. Trust the tale. The proper function of a critic is to save the tale from the artist who created it... If it be really a work of art, it must contain the essential criticism of the morality to which it adheres. ${ }^{124}$

This is not only compatible with the ideas of deconstruction we have been looking at; it is how deconstruction came to understand the nature of language and judgment in the first place. ${ }^{125}$

\section{Justice}

The unceasing and incurable struggle with uncertain meaning, multiple perspectives, and ever-changing context is our true ethical predicament. We can neither deny it, as the positivists claim,or transcend it, as the Romantics suggest.

\section{Of course living with uncertainty is uncomfortable; thereby we experience judgment not as the manifest knowledge of what is right and fitting, but as the energized field of doubt that requires justification in human terms and in which such justification is always inadequate, always subject to challenge and revision.}

This takes us back to Derrida's Force of Law, one of the key texts in the movement of law and the humanities. The tension between justice as sameness and justice as difference, between judgment as calculation and judgment which recognizes the incalculable and the singular, is irreducible."Between justice (infinite, incalculable, rebellious to rule and foreign to symmetry) and the exercise of justice as law or right, legitimacy or legality, stabilizable and statutory, calculable, a system of regulated and coded prescriptions" 126 we cannot choose since our belief in these two aspects is neither synthesizable into a unity nor prioritizable into a hierarchy.

These inescapable contradictions, however, are not problems for the moment of judgment - they are productive. As Derrida points out, responsibility and accountability are not opposites or choices: they are incommensurable forces that provide us with a deeper understanding of each though we are constantly forced to betray them as we attempt to realize them. ${ }^{127}$ In language too, communication and expression pull
123 DH Lawrence, Study of Thomas Hardy and other essays (Cambridge: Cambridge University Press, 1985 [1923], 179; see also 172.

124 DH Lawrence, Studies in Classic American Literature (New York: Viking Press, 1964 [1923]), 2.

125 Jacques Derrida, Acts of Literature, ed.
Derek Attridge (London \& New York: Routledge, 1992); esp 'Before the Law' 189 and 'The Law of Genre' 222.

126 Derrida,"Force of Law," 959; see also"Before the Law".

127 Derrida, Gift of Death. 
meaning in strictly opposite directions but paradoxically open wide the warp of language to creativity, dialogue, and change. ${ }^{128}$ Finally, in his late work on hospitality, he speaks of a"tension at the heart of the heritage" between forgiveness as the unconditional pardon of the guilty as such, and forgiveness as a conditional grant in an economy of repentance. ${ }^{129}$

These two poles, the unconditional and the conditional, are absolutely heterogeneous, and must remain irreducible to one another. They are nonetheless indissociable: if one wants, and it is necessary, forgiveness to become effective, concrete, historic; if one wants it to arrive, to happen by changing things, it is necessary that this purity engage itself in a series of conditions... It is between these two poles, irreconcilable but indissociable, that decision and responsibilities are to be taken. ${ }^{130}$

Likewise in the moment of legal judgment the words which we are called on to interpret are likewise neither transparent instruction machines, nor yet the memory of essences, but a polarized field of differences, crackling with energy. There is an inescapable tension irreconcilable but indissociable - between the prior rule, general and certain, and the question of its application in this case. Now this gives no comfort to the positivists who think that the prior rule can be relied upon to simply tell us what is required in this case. But neither does it give comfort to the transcendentalists. The beyond-the-rules is not a circuit-breaker: it is a circuit maker. This tension forces us to rethink our rules, and the meaning we give to our words, and the imagined 'essences' of those words, and the purposes served by them: we are forced to reconsider, to question, to doubt. But this tension is ended only by a new judgment which attempts to re-impose stability on the legal order. ${ }^{131}$ This generates, immediately if not sooner, a new polarity, and new tensions.

Justice, therefore, does not lie in the imperfect legal judgment itself, but rather in the doubt and the challenge that went with it, on the one hand, and the discourse of justification, reason-giving, and resistance that continues the circuit into the future, on the other. Legal judgment is on this view exactly opposite to the closure and finality - the death wish or Thanatos of discourse - to which both Romanticism and positivism, in their very different ways, are drawn.

This leads me back to my early puzzle about how to develop a notion of judgment that would give some meaning to the 'rule of law' without falling into either positivism or Romanticism. As Berkowitz so powerfully shows us, 'reason' in the orthodox structure of positivism is meant to lead to a single 'right answer' to legal judgments, grounded in the faith that logic and science can provide lawyers and citizens with objective and determinate answers to their legal problems. The rule of law, on this understanding, makes a fetish of certainty that sacrifices everything to the tyranny of an ever-growing heap of gesetz. ${ }^{132}$ I certainly agree that this promise is destined to fail.

It does not follow that we should give up on judgment as the giving of 'reasons,' now in the plural. The rule of law might instead offer us a promise that decision-makers be required to articulate and justify their decisions, and to be
128 Derrida, Of Grammatology.

129 Jacques Derrida, "Forgiveness," in On Cosmopolitanism and Forgiveness, trans. Mark Dooley and Michael Hughes (Routledge: London, 2002) 34-5; see also the Introduction by Simon
Critchley and Richard Kearney, e.g. at x-xi. 130 Id., 44-5.

131 Derrida, "Afterword" in Limited Inc., 148.

132 Berkowitz, The Gift of Science, 94-7.

58 Revista Forumul Judecătorilor - Nr. 1/2013 
challenged on their reasons, forced to question them and think again, without ever simply being able to appeal to their authority or their insight as some kind of ineffable trump. The rule of law cannot deliver a grounded truth about law nothing can. But it can deliver a discourse through which those who judge and interpret the law remain answerable, engaged in a dialogue of listening with those who come before them and after them. When we reflect on whether to apply a rule in some new circumstance, or whether to apply this rule or that, we are forced to think about the notion of justice behind that rule in a way that is not capable of being nailed down in advance. But because justice is unattainable, because there is a necessary imperfection to this process, the obligation to render a judgment is not severable from the obligation to expose one's judgment, to explain, justify, and be subjected to critique for it. Correction is the soul of justice. Were it not for that, the endless return of deconstruction would be short-circuited by some appeal to a foundation - nature or tradition or authority - that it was Derrida's implacable goal to expose as a metaphysical version of the shell-and-pea trick.

Accordingly, legal judgment is the province of neither technicians nor gurus. It is the province of us all, a ceaseless and participatory social discourse. Without the giving of reasons and the pressure of justification, however provisional and protean, the law would cease to offer us - all of us, whether as citizens or as lawyers or as judges - the possibility of learning something new about ourselves and the world. Just as recent trends in literature (the judgment of fiction) have striven to dethrone the solitary genius in favour of readers' active participation in the construction, interpretation, and crucially, the transmission of meaning over time; so too similar trends in our thinking about justice (the judgment of law) have dethroned the solitary judge in favour of citizens' active participation in legal discourse. Just as with literature and philosophy, the influence of the humanities on law makes the process of judgment more contentious and continuous, but at the same time more democratic than ever before.

The word 'insight," which is Berkowitz' alternative to rule-following, appears a purely in-ward process by which one intuits the big picture and discovers what justice just is. To speak of law as an inspired insight"that grows of its own accord" or as a"natural or traditional insight into what is right and fitting", suggest precisely an intuition that comes without the need for interrogation, or modification, or argument, but simply as a divinely ordained fact. Insight is not transformed by argument or effected by resistance - it is "free". Insight is not transformed by time or reflection - it is "manifest" and"divine". ${ }^{133}$ Berkowitz' profound hostility to law as"the modern approach of giving reasons and justifications"134 appears to confirm this reading: reason and justification mark the impoverishment of law. ${ }^{135}$ To my way of thinking, nothing is free, or natural, or manifest. What we learn about justice, and of course this changes over time in a world of bewildering complexity and constant motion, we earn, like a novel's gradually ramified understanding, precisely through processes of justification and reason-giving.

Insight and reasons are not somehow opposite. On the contrary, they stem from

133 Id., 29, 51, 24.

134 Id., 156.

135 Id., e.g. at $51,52$. 
each other. The same is true of teaching, which is not the mere manifestation of insight but its slow emergence under the relentless demands of our students that we give reasons and explain our views. As Tobias Wolff writes,"Teaching made him accountable for his thoughts, and as he became accountable for them he had more of them, and they became sharper and deeper." 136 Insight is collective, chiseled out of us by the constant demands and interrogations of others; the painful result of reasons and not the transcending of them. It is conscience knowledge shared with others - and not, in the old Anglo-Saxon word, 'inwit'. Without the giving of reasons there would be no insight at all: not reason - singular - in the limited sense of the authority of pure reason or the dictates of logic, but in the broader sense of reasons - plural that encompasses the articulation of positions, the challenge of justification, and the to-and-fro of reflection. Justice, similarly, is not a process by which those in authority teach us mortals, but a process by which, under the pressure of reasons and the demands to justify, they come to learn from them. ${ }^{137}$

\section{Conclusion}

So the two alternatives which law and the humanities offers to positivistic theories of judgment, though both draw on a similar heritage and richly imbued with its spirit, yet end up inhabiting dramatically different worlds. Again, Berkowitz is exemplary in refusing ever to shy away from the logic of his position. Since the nature of the insight into justice is entirely without the trappings of discourse, it"cannot but appear to others as "lawless caprice."'138 But legal systems that abandon all efforts to justify and give reasons, and refuse to open themselves to question, very often resort to some appeal to nature or authority or tradition. I suspect that this moment really does tend to usher in the reign of lawless caprice or the revolutionary justice of a kangaroo court.

In the moment of judgment, justice is always incomplete or lacking: this lack is its beauty and its strength. Of course living with uncertainty is uncomfortable; thereby we experience judgment not as the manifest knowledge of what is right and fitting, but as the energized field of doubt that requires justification in human terms and in which such justification is always inadequate, always subject to challenge and revision. This is, perhaps, what the literature of the novel contributes most in our thinking about judgment. It takes the smallness, and the inadequacy, and the goddamn perversity of us, and it does so without yearning for a time when gods and heroes roamed the earth; without ever waxing nostalgic about the whole that lives no more. Instead, these marvelously imagined narratives take our smallness and inadequacy and fragmentation seriously. They make of it something that can be seen, truly seen in all its incoherent detail - and something thereby capable at last of being loved.

The rule of law, thus re-imagined, is not the outcome of a foundation but a process of continually challenging them; it is governed by reasons but not reason; it offers a discourse by which the law learns and not a declaration by which it instructs. Enlivened by literature as well as philosophy, it becomes a polarity and not a unity; the expression of restless dialogue and never the manifestation of
136 Tobias Wolff, Old School, (New York: Vintage, 2003) 181-2. Berkowitz' own vision of teaching seems dramatically different: see 159-60.
137 Bob Gibbs,"The Other Comes to Teach Me" (1991) 24 Man and World 219-233.

138 Berkowitz, The Gift of Science, xvi. 
a unifying transcendent insight. This is, of course, all too human and imperfect. But whereas positivism glorifies the inhuman in law so as to eradicate imperfection by removing the judge from judgment, and Romanticism glorifies the superhuman in law so as to transcend imperfection by exalting the judge's judgment, deconstruction glorifies in nothing but this imperfection. Against the gift of science and the siren song of nature, then, we might defend a rule of law and a theory of judgment full of the beauty and doubt of literature: not a way out, or a way back, but a way in and on.

Nota redacției: Articolul a fost publicat inițial în ANU College of Law Research Paper No. 12-42, Revista Forumul Judecătorilor primind permisiunea autorului și a revistei americane în vederea republicării exclusive a studiului în România. 


\title{
What do Courts Have to do with it?: The Judiciary's Role in Making Federal Tax Law
}

\author{
Leandra Lederman*
}

\begin{abstract}
:
The Internal Revenue Code is an important source of federal tax law, but it is not the only source. The U.S. Department of the Treasury and Internal Revenue Service issue important guidance, and federal courts interpret all of these authorities. This essay provides an overview of federal tax litigation, at both the trial and appellate levels, and discusses the interplay among Congress, the Treasury, and the judiciary in developing federal tax law.
\end{abstract}

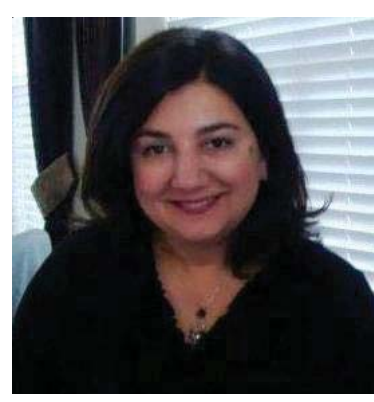

\section{Rezumat:}

Codul privind veniturile bugetare este un izvor important de drept fiscal federal, dar nu este singurul izvor. Departamentul de Stat al Statelor Unite privind Trezoreria și Serviciul de Taxe și Impozite emit norme metodologice importante, iar instanțele federale interpretează toate aceste izvoare de drept. Acest articol oferă o privire de ansamblu asupra litigiilor fiscale, atât în primă instanță cât și în căile de atac și analizează interacțiunea dintre Congres, Trezorerie și instanțele judecătorești î́n dezvoltarea legislației fiscale la nivel federal.

Keywords: federal tax law, federal tax litigation, taxpayers, general administrative law principles, Internal Revenue Service (IRS)

\section{Introduction}

$\mathrm{T}$ he Internal Revenue Code (Code) generally is the first place to look when con fronting a federal tax question, but it is important to recognize that much federal tax law is not statutory. The U.S. Department of the Treasury (Treasury) promulgates regulations, and the Internal Revenue Service (IRS) issues important guidance, such as Revenue Rulings, Revenue Procedures, and Notices (Hickman, 2009). Federal courts interpret all of these authorities. In order to understand and apply federal tax law, it is important to appreciate the role that federal trial courts, Courts of Appeals, and the U.S. Supreme Court play in developing the law. This essay provides an overview of federal tax litigation, discusses the deference courts give to guidance issued by the Treasury and IRS, and discusses when taxpayers have "standing" to challenge the tax laws in court. The essay also discusses cases in which Congress may step in to amend the Code following a court decision.
* E-mail professional contact:

llederma@indiana.edu.

Professor Leandra Lederman is the William W. Oliver Professor of Tax Law and Director of the Tax Program at the Indiana University Maurer School of Law. She teaches Federal Income Tax, Corporate Tax, Tax Procedure, and Tax Policy Colloquium. 